\title{
Studies on the Relationship between Desertification and Forest Policies in China
}

\author{
Hongyi Chen $^{* 1}$ and Yasuaki Kurokawa*2
}

\begin{abstract}
Desertification has become such a serious issue that there is a pressing need for us to resolve it immediately. Nearly 20 percent of China's land territory has turned to desertified land due to natural and human factors, and overall desertification continues worsen. The policy of forest exploitation and monoculture in China is the primary cause that has led to disastrous consequences, including degradation of forests and landscapes, serious soil erosion and catastrophic flooding, and especially deforestation. In order to resolve this desertification and realize the sustainable development of forestry, the Chinese government has begun to modify Chinese forest policies and make a series of plans and programs on forest resources and combating desertification. Hence there have been many statutes with provisions relating to forest conservation. Although since the "reform and opening", much has been done in reforming Chinese forest policy, the situation of the desertification is still worsening. In this paper, we will analyze the relationship between the desertification and current Chinese forest policy in order to develop an adequate forest policy system to control and resolve the desertification and to realize sustainable development of the environment in China.
\end{abstract}

Keywords: desertification, forest policy, sustainable development of environment, China

\section{INTRODUCTION}

Desertification is one of the most serious environmental and social economic problems in the world that has been harming China for a long time. Desertification has brought about environmental deterioration and land degradation, which have caused heavy losses in the economy. Therefore, it is absolutely necessary to implement project for combating desertification. According to the research and practices of nearly 50 years, we consider that land degradation from desertification has mainly resulted from interaction between excessive human activities and vulnerable environment (ZHU, 1989). In the past 20 years, great achievements and experience have been obtained in the technology and typical models for combating desertification in China. Although the study and

${ }^{* 1}$ United Graduate School of Agricultural Science, Tottori University, 680-0947, Koyama Minami 4101, Tottori-City

${ }^{* 2}$ Department of Forest Science, Faculty of Agriculture, Tottori University, 680-0947, Koyama Minami 4-101, Tottori-City countermeasures against desertification have been made for nearly half a century, the danger of desertification has become more and more serious. There have been some studies that show that the forest policy factor is the main cause of the desertification in China. Since the "reform and opening", China has taken a series of measures to cope with this issue. National policies, plans and projects on forest conservation were adopted and implemented over the past two decades. Forest conservation objects were set forth for short, middle, and long terms. The logging of natural forests has been banned by the government in recent years. In addition, China has established a legislative framework on forest conservation consisting of constitutional clauses, statutes and regulations, as well as local regulations. However, the desertification continues to worsen. In the $60 \mathrm{~s}-70 \mathrm{~s}$, the expanding speed was $1,560 \mathrm{~km}^{2}$ each year; in the $80 \mathrm{~s}$, it was $2,100 \mathrm{~km}^{2}$ each year; in the $90 \mathrm{~s}$, it has reached $2,460 \mathrm{~km}^{2}$ each year (FENG, 2003). Therefore, it is necessary for us to examine our current forest policy system for flaws and to make further forest policy reforms.

\section{THE SITUATION OF DESERTIFICATION IN CHINA}

Desertification in China is very serious and has become 
one of the main environmental problems. Desertification are mainly distributed in arid, semi-arid and dry sub-humid areas, covering 471 counties in 18 provinces and autonomous regions in the west part of Northeast China, the northern part of North China and in most regions of Northwest China (ZHU, 1999) (see Fig. 1). In the arid and semi-arid regions of North China the main aspect of degradation is desertification (including shifting sand dunes, sand dune reactivation, shifting sands spreading into grasslands and wind erosion in dry farmland). It covers about $334,000 \mathrm{~km}^{2}$, of which $197,000 \mathrm{~km}^{2}$ has already been desertified and $137,000 \mathrm{~km}^{2}$ is being threatened in the process. A population of about 35 million people is affected. By comparing and interpreting aerial photographs taken at the end of the 1950s and the middle of the $1970 \mathrm{~s}$, we note that the desertified land has increased from the previous $137,000 \mathrm{~km}^{2}$ to $176,000 \mathrm{~km}^{2}$. In other words, $39,000 \mathrm{~km}^{2}$ of land was desertified during this 15 year period, an average annual loss of $1,560 \mathrm{~km}^{2}(\mathrm{ZHU}, 1999)$. From the view point of spatial distribution of the desertification in the last 10 years, the following points are worth mentioning:

1. The dry farmlands in the sandy steppe region represent territories prone to desertification or land with high rates of ongoing desertification. In the last 10 years the desertification of grassland has developed at the annual spread rate of desertified land reaching 5-10\% (FENG, 2003).

2. In some pre-existing desertified regions such as sandy land in Horqin and along the Great Wall in SHaanxi province, recent development and the adoption of some control measures has reduced the rate of desertification. The annual spread rate varies between 2-5\% (FENG, 2003).

3. In the last 10 years, desertification of grasslands has also developed very quickly. For example, in the north pan of the Ulanqab league the desertified land area has increased from $18.1 \%$ in the 1970 s to $30.4 \%$ in the $1980 \mathrm{~s}$. It is characterized

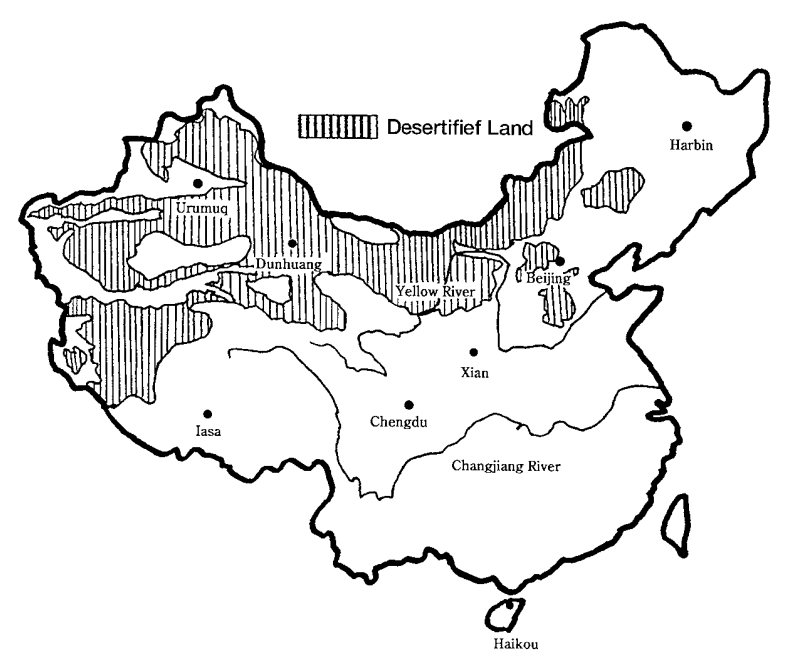

Fig. 1 The distribution of desertification in China by the ground surface becoming rough, the appearance of shifting sand and the deterioration in quality of the grasslands (FENG, 2003).

4. When some control measures were adopted over 10 years ago, the spatial range of desertified land has contracted. In the southeast part of the sandy land in MuUs, after 10 years of rehabilitation, the vegetative cover has increased from $10 \%$ to $23 \%$, the total grain yield increased by $32 \%$ and average personal income increased 7 times (FENG, 2003).

5 . In desertified regions with "ecological elasticity" in the semi-arid zone, desertified land can be rehabilitated in 5-7 years as long as some measures are adopted, including readjustment of the land use structure, fencing to exclude grazing animals, and afforestation and stabilization of shifting sand dunes. This can be seen, in particular, in the Huihe region of Hulun Buir steppe where the natural condition is better than other sandy areas. The desertified land has been transformed into woodland of Pinus sylvestris (ZHANG, 2002).

\section{THE DEVELOPMENT OF CHINESE FOREST POLICIES}

The development of desertification in China is a process of national exploitation policies being carrying out at different times in history. That is to say, unsuitable forest policies at different times in history have caused and aggravated the desertification. And at the same time, the desertification problem has led to forest policy reform. The development process of Chinese forest policy can be divided into the following three periods:

\section{Early Period of China's Foundation (1949-1978)}

In the early years of the People's Republic of China, the government pursued a forest policy characterized by tree planting on barren lands and timber harvesting in major forest regions, while expressing concern about forest protection. Large-scale tree planting in the wastelands, especially in the north, began in the mid period of the $1950 \mathrm{~s}$.

Apart from tree planting, a theme characterizing Chinese forestry to the present, which was the main focus of the forestry sector was timber production. However, the "Big Leap Forward" campaign launched in 1958 encouraged the use of homemade furnaces for steeling making, but that led to thousands of inefficient furnaces and massive destruction of forests. The compulsory elevation of millions of peasants' cooperative to people's Communes, along with the failure of "the Big Leap Forward", contributed to a famine that lasted for three years (1960-1962). Nationwide calamities and tragedies forced the central government to readjust policies and adopt measures to relax taxation riles in rural areas. In the countryside, for example farmers were allowed to retain more agricultural produce on collectively-owned land. This enabled the national economy to recover rather quickly. Forest industries began to grow rapidly with the opening of the Great 
Xingan Mountains in the northeast and the Jinsha River forest region in the southwest in the 1960s. However, the Cultural Revelution (1966-1976) catapulted China into unprecedented political chaos and anarchy. During this period, most forestry programs were discontinued, except for rampant timber cutting and highly inefficient afforestation campaigns.

For three decades prior to the 1978 economic reforms, the forest sector supplied under-priced logs to support the national economic development. Although many professional foresters appealed for the protection of the ecosystem and wildlife habitat, for increased investment in silviculture, the sector was seen only as a supplier of cheap raw materials. As a consequence, while over one billion cubic meters of timber was supplied nationwide during the period 1949-1979, the country's forest resources base was devastated. Achievements on the tree-planting front were dismal: out of a total of 104 million ha planted during the same period, the rate of success was a mere $20 \%$. The perform period was characterized by rhetoric-laden campaigns aimed at mass mobilization for tree planting and by unsustainable timber harvest in primary forest areas (RICHARDSON, 2000).

The proportion of growing stock destroyed in these provinces during the Great Leap Forward ranges from one third (Hunan, HubeI) to one tenth (Sichuan) (ZHu, 1999). The situation in many other provinces was no better (the datum for other provinces in Table 1). This trend of declining forest coverage during the Great Leap Forward continued through the early 1980 s.

During this period of the "Great Leap Forward" and "Cultural Revelution", the study of combating desertification was greatly affected, and was even forced to be at a standstill. In the mid-1950s, China began exploring the vast resources of the Great Xingan Mountain forest. Since then, the average forestry line has retreated 50 kilometers due to over logging and forest resources were reduced greatly (see Table 2 and 3). With the great movement of opening up the wasteland, a great

Table 1 The change of forest coverage (the provinces with serious desertification)

\begin{tabular}{|c|c|c|c|c|c|}
\hline \multirow{2}{*}{ Year } & \multicolumn{5}{|c|}{ Province } \\
\hline & Hebei & Shanxi & Gansu & Ningxia & Qinhai \\
\hline 1948 & 126 & 971 & 2,285 & 59 & 1,456 \\
\hline 1976 & 2,010 & 1,090 & 1,87 & 60 & 190 \\
\hline 1981 & 1,677 & 810 & 1,769 & 95 & 195 \\
\hline 1988 & 2,011 & 893 & 2,029 & 118 & 266 \\
\hline
\end{tabular}

Source: Zhu (1999)

Table 2 Chin ese forest resources

\begin{tabular}{|c|c|c|c|c|c|c|}
\hline \multirow{2}{*}{ Forest type } & \multicolumn{2}{|c|}{ Young and Middle-aged } & \multicolumn{2}{|c|}{ Mature and Over-mature } & \multicolumn{2}{|c|}{ Total } \\
\hline & Area $\left(10^{6} \mathrm{ha}\right)$ & Volume $\left(10^{6} \mathrm{~m}^{3}\right)$ & Area $\left(10^{6} \mathrm{ha}\right)$ & Volume $\left(10^{6} \mathrm{~m}^{3}\right)$ & Area $\left(10^{6} \mathrm{ha}\right)$ & Volume $\left(10^{6} \mathrm{~m}^{3}\right)$ \\
\hline Timber forest & 74.0 & $3,368.6$ & 25.4 & $3,837.6$ & 99.4 & $7,206.2$ \\
\hline Shelterbelts & 11.9 & 554.0 & 9.5 & $1,639.0$ & 21.4 & $2,193.0$ \\
\hline Fuelwood forest & 4.2 & 66.9 & 0.3 & 20.6 & 4.5 & 87.5 \\
\hline Special forest & 1.8 & 161.7 & 2.1 & 437.3 & 4.0 & 599.0 \\
\hline Total & 91.9 & $4,151.1$ & 37.3 & $5,934.5$ & 129.2 & 10,086 \\
\hline
\end{tabular}

Souce: SFA (2000)

Table 3 Chinese forest resources (1949-1995)

\begin{tabular}{lcc}
\hline \multicolumn{1}{c}{ Period } & Forest Area $\left(1,000 \mathrm{~km}^{2}\right)$ & Forest Coverage $(\%)$ \\
\hline Before 1949 & 1,340 & 13.92 \\
Early Period (1950-1972) & 760 & 8.90 \\
1st National Survey (1973-1978) & 1,220 & 12.70 \\
2nd National Survey (1979-1984) & 1,152 & 12.00 \\
3rd National Survey (1985-1990) & 1,246 & 12.98 \\
4th National Survey (1991-1995) & 1,336 & 13.92 \\
\hline
\end{tabular}

Source: SFA (2000) 


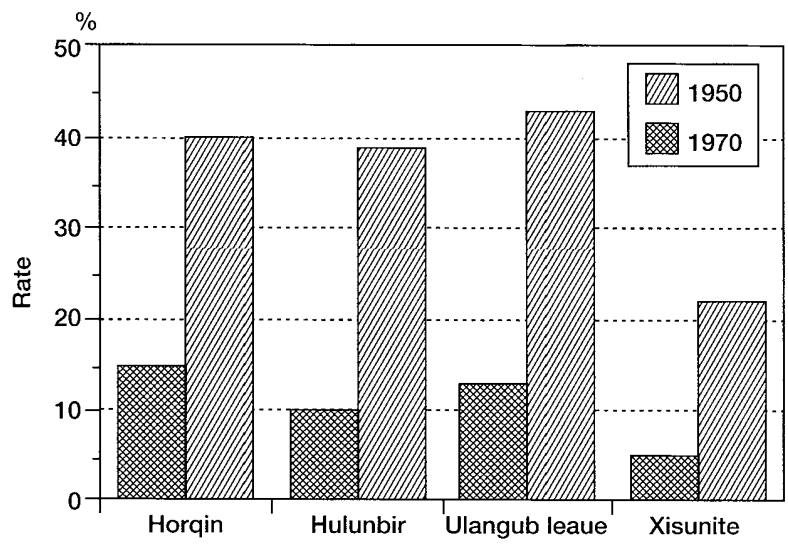

Fig. 2 The rate changes of flowing tunes

number of mountains and grassland were destroyed, that flowing tunes were spread more widely, and desertification became more serious (see Fig. 2). The statistical data shows the situation of flowing tune changes in this period.

By comparing and interpreting aerial photographs taken at the end of the 1950 s and the middle of the 1970 s, we note that the desertified land has increased from the previous $137,000 \mathrm{~km}^{2}$ to $176,000 \mathrm{~km}^{2}$. In other words, $39,000 \mathrm{~km}^{2}$ of land was desertified during this 15-year period, an average annual loss of $1,560 \mathrm{~km}^{2}$ (ZHU, 1989).

\section{Early Period of Reform (1978-1985)}

In 1978, the Chinese government decided to promote forestry by providing the Ministry of Forestry with the mandate, among other things, to oversee timber production in state-owned forests and afforestation across the country. Due to central planning, the Ministry functioned on administrative linkages with forestry departments at the provincial level, forestry bureaus at the country level, and work stations at the grass-roots level of township. In the meantime, the Chinese Academy of Forestry, which came into being in 1958, was strengthened and several forestry colleges were expanded under the auspices of the Ministry.

On the other hand, another focus was on the rural reform. Public ownership was the main focus for rural forest, while various economic elements coexisted. A breakthrough was made in the establishment of pluralistic, multi-level and multitype forestry management entities.

As a result of a series of reforms in the administrative hierarchy in the late 1980s and early 1990s, the Ministry of Forestry can focus on administration as well as the formulation of policies, leaving production decisions and operations to the companies (WANG, 2001).

Although improvement has been made in forest area and storage by the early 1990 s, there is still a big disparity between the supply and demand for timber. The reason is that the increase in forest area and storage is mainly due to the growth
Table 4 The reduction of forest resource (timber forest)

\begin{tabular}{ccccccc}
\hline \multirow{2}{*}{ Period } & \multicolumn{2}{c}{ Total } & & \multicolumn{2}{c}{ Mature timber } \\
\cline { 2 - 3 } \cline { 5 - 6 } & $\begin{array}{c}\text { Area } \\
\left(10^{5} \mathrm{ha}\right)\end{array}$ & $\begin{array}{c}\text { Store } \\
\left(10 \mathrm{~m}^{3}\right)\end{array}$ & & $\begin{array}{c}\text { Area } \\
\left(10^{5} \mathrm{ha}\right)\end{array}$ & $\begin{array}{c}\text { Store } \\
\left(10 \mathrm{~m}^{3}\right)\end{array}$ \\
\hline $1977-1981$ & 8,243 & 639,951 & & 2,188 & 384,593 \\
$1984-1988$ & 7,958 & 615,752 & & 1,419 & 262,164 \\
Increment & -285 & $-78,199$ & & -769 & $-122,430$ \\
Annually & -40 & $-11,171$ & & -110 & $-17,490$ \\
\hline
\end{tabular}

Source: CFD (1998)

of young forests unsuitable for logging. The existing area and storage of mature and over-mature forests is not large enough to maintain a sustainable yield of timber. They cannot even afford to meet the rather low level of timber consumption in China. The annual deficit of standing forest storage from 1984 to 1988 was 40 million cubic meters. Basically two methods were applied to fill the disparity (see Table 4) and lower reaches. One was to log more of the exciting mature and covermature forests; the other was to import timber. Both methods were not adequate. The first one intensifies the timber deficit; the second not only causes a large financial burden, it also increases pressure on world forest resources.

The loss of forest-coverage has caused serious ecological problems:

\section{Soil erosion:}

The Yellow River is famous for her muddy waters. The soil and sand in the water come from the upper and middle reaches of the river. In these areas, forest coverage has been gone for thousands of years. In another major river basin, the Chang Jiang River, the soil erosion area increased from 360 thousand square kilometers in the 1950 s to 560 thousand square kilometers by the 1980 s. The loss of forest coverage in the upper and middle reaches of the river is one of the main causes of the destruction in the middle and lower reaches.

\section{Desertification:}

The loss of forest-coverage has caused the expansion of desert in northern and northwestern China. Every year, 170,000 hectares of land turn into desert. Farmland and grasslands are damaged by sandstorm disasters. In the northwestern, northern and northeastern areas, 13,33 million hectares of farmland and 100 million hectares of grassland suffer from sand storm disasters each year.

\section{Devolution in Forest Tenures Period (1985-present)}

In 1998, the Chinese government established the NFCP (National Forest Care Program), which articulated the new forest policy. Its purposes were to restore natural forests in ecologically sensitive areas, to plant forests for soil and water protection, increase timber production in forest plantations, to protect existing natural forests from excessive cutting, and maintain the multiple-use policy in natural forests. The NFCP 
applies to 18 provinces and autonomous regions, which contain the upstream regions of major river systems, including specifically the Yellow and Chang Jiang Rivers, which have suffered massive ecological and environmental degradation during the past 50 years. The target area is divided into two priority regions. The state forest regions are classified as the first priority for the NFCP. The two priorities receive different levels of financial support from the central government, ranging from 20 to $100 \%$ of all costs.

By the mid-1980s, a great number of collectively-owned woodlots had been distributed to peasants under a variety of contractual forms that granted them an entitlement to the forested land and its harvest. The changes in forest tenures have been recognized as a crucial driver in China's forest policy reform (RICHARDSON, 1990).

Despite thousands of years of human land-use, large areas of old-growth forest still existed in China at the beginning of the 20th century. Before the $1950 \mathrm{~s}$, most of China's forests have been naturally regenerated. Since then, demand for timber has resulted in extensive cutting of forests, and timber harvests increased from 20 million $\mathrm{m}^{3} /$ year in the 1950 s to 63 million $\mathrm{m}^{3} /$ year in the $1990 \mathrm{~s}$. Government policy did not require that native tree species be planted after logging, but promoted planting of fast-growing tree species, such as larch (Larix spp.), poplar (Populus spp.), and Chinese fir (Cunninghamia Lanceolata). Although a large-scale increase of plantation-style forests in non-forested areas increased the total forest coverage in China from $5.2 \%$ in 1950 to $13.9 \%$ in 1995 , natural forests declined to $30 \%$ of the total forest area in China and unit-area stocking of natural forests decreased by 32\% (China Environmental Review, 1999) (see Table 4 and 5).

China's human population has increased about 2.5 times over the past 50 years, yet the human population in forested areas has increased five-fold. Scientists foresaw the potential conflict between human population growth and forest resource use and began advocating changes in China's forest policy as early as the 1960s. They had little success. In the 1970s, government policy limited clear-cut areas to $<10$ ha in northeastern China, but departures from this standard were routine in field application. During the 1990s, eroded lands continued to increase by $>10,000 \mathrm{~km}^{2}$ annually, with the result that $38 \%$ of China's total land area is now considered badly eroded (CHEN, 1998).

The sharp decline in the quantity and quality of natural

Table 5 Growth and consumption

\begin{tabular}{ccccc}
\hline Period & $\begin{array}{c}\text { Annual Growh } \\
\text { (ha) }\end{array}$ & $\begin{array}{c}\text { Consumptin } \\
\left(\mathrm{m}^{3}\right)\end{array}$ & $\begin{array}{c}\text { Deficit } \\
\text { (ha) }\end{array}$ & $\begin{array}{c}\text { Mature Timber } \\
\left(\mathrm{m}^{3}\right)\end{array}$ \\
\hline $1977-1981$ & 2.940 .19 & 2.75 & 0.644 & \\
$1984-1988$ & 3.16 & 3.44 & 0.28 & 0.961 \\
Growth $(\%)$ & 14.90 & 17.01 & 47.36 & 49.22 \\
\hline
\end{tabular}

Source: SFA (2003) forests resulted in loss and fragmentation of natural habitats. At least 200 plant species have become extinct in China since the 1950 s, and $>61 \%$ of wildlife species have suffered severe habitat losses. Valuable and rare species, such as ginseng (Panax Ginseng) are threatened with extinction. Changes in forest composition have also caused severe ecological and environmental disasters. Insect infestations have damaged $>9.3$ million ha of forests per year, causing $>10$ million $\mathrm{m}^{3}$ of timber loss. Flash flooding, partly due to loss of natural vegetative cover, caused a total loss of 166.6 billion yuan (RMB, US $\$ 20$ billion) in the summer of 1998 alone (CHEN, 1998).

The degradation of natural forests was inevitable because the old forest policy was designed to maximize timber production for economic development, and in its implementation, the amount of timber harvested exceeded that which was sustainable by at least a third; natural forest conditions were not accurately and systematically monitored, and no effective effort was made to evaluate the old forest policy.

In general, in the traditional high consumption extensive economic rising pattern, a public-owned system of forest resources is not suitable for sustainable management of the forest. It is also impossible to form an effective running system for sustainable development of the ecological environment and forestry economy. It shows that the desertification in China was mainly caused by unsound forest policies and in the view of combating desertification and making sustainable development in Chinese forestry, the reform of Chinese forest policy reform has become an extremely urgent task.

\section{ANALYSIS}

The information above shows that from 1958 to 1980 , there were three forest deforestations in China, which were the disasters during the changing process of Chinas forest resources. In 1976, the forest coverage in China was only $12.7 \%$. The basic causes for the three forest deforestations were no perfect legal system, the property right of forest was not steady, the legalization of property rights was neglected. After reviewing the history of forest development in China, we found that though the historic background was different, and there was a variety of causes, it is the same that the property right of forests, forest land was not steady and the policies couldn't effectively protect the benefit of the owners or users. Factors associated with deforestation and desertification usually have a strong human component, indicating that they often result from policies formulated by decision-makers at various levels. In fact, policy is increasingly targeted as a starting point for understanding the elements driving both deforestation and desertification, and eventually for reversing the trend. Simple agricultural structure and employment access, animal husbandry and rigid forest policy are the direct reasons leading to deforestation and desertification. In order to combat desertification and implement environmentally sustainable development, in 1992, China's reform of the 
economic system entered into the third and the key period. The Decision of Several Issues Concerning Establishment of the Market Economic System was adopted by the Plenary Session of the Fourteenth CPC Central Committee in 1993. The supplementary reform of taxation, finance, prices and foreign exchange was undertaken in 1994, which pushed the implementation of the open-door policy and the development of the socialist modernization into a new period (LI, 2002). During this period, China's forestry entered into a comprehensive and supplementary reform period. However, the Chinese forestry reform does not stop the desertification expanding trade and also is unable to adapt the present economic system. It is well known that forestry shoulders heavy tasks of treating soil and water erosion, water source conservation, combating desertification and alleviation of natural disasters, etc. Combating desertification is not only the one of the task of forestry but also the comprehensive reflection of the others. Therefore, the present forest situation shows that forestry is facing some sharp contradictions at a deeper level, seriously restricting forestry development and realization of development goals. The major problems are:

In the forest policy, forest source property right is the key problem and it is also one of the main causes of deforestation. Most of the forest policy was made in the planning economic period. It is the reflection of a socialistic public-owned system in forest resources property right system. In the following reform, the proprietary right breaking away from managerial rights, forest property rights and managerial structures were improved in some way, but the reform goal is to stress economy and weaken farmers' benefit. It is only an innovation of the economic distribution system. The reason for the forest resources property right system changing by period is that the first is the people's subjective limitation, especially to socialistic nature and task. The second is the limitation to forest function, ignored the important affection of forests in construction of environment development and the policy of laying on logging and neglecting planning led to the excessive consumption. The two aspects are the main subjective reasons, and the objective reason is our environmental awareness behind the times. These are the main reasons affecting forest policy reform and preventing ecological development. In the end of twenty century, there was a serious flood. When people were faced with the great loss of lives and properties, the attitude towards forest resources changed, and they paid more attention on the preventing function of forests. The government began to reform the forest policy and invested several million yuan to start six key forest projects, including the famous Sanbei Shelter Forest Project. There is no doubt that these projects are valuable in prevent and rebuilding the ecological environment, but it is well known that ecological prevention is a long-term task and needs much expenditure for a long period of time. But China is still a developing country; the fiscal solvency of the central government and local governments are limited. There is not that much capacity to support these projects. Therefore, it is impossible to ecological prevention only by the government investment. The only choice is to arouse the whole social forces to participant. Then the question is, how to lead the social fund, labor, management and technology to ecological prevention? The way is to make liberal policy to abstract social forces. When we use material benefits as a guide, we will face further forest policy reform, that is to say, forest resource property right system reform.

\section{CONCLUSION}

From the perspective of the forest ecological prevention, social forestry mechanism is the trade of the world. It can overcome the expansion of private property economic benefit and cut down expenses for managing public welfare forests. In general, it can promote efficiency of forest management.

Social forest mechanism means that forests are managed by local people (living near or in the concerned forest area) for their own benefit. Social forest mechanism comprises of others community forestry, private forestry and lease-hold forestry (TAYLOR, 2000)

Social forest mechanism is that forests, forest land and forestry production are managed by the local people in a participatory way and their own benefit. It includes plantation, forest protection, harvesting and processing; benefit considers both material and immaterial benefits (including ecological and environmental aspects). Social forestry can provide the participants with an opportunity to improve their knowledge and technical skills. The participants are expected to have:

1. Fully understood the concept of social forestry and its usefulness in enhancing forest conservation and mitigating desertification in the region.

2. Development their abilities in policy formulation to promote Social forestry, which enable the application of social forestry strategies to various local conditions of participating countries.

3. Learnt effective measures to be taken to disseminate the practices and relate techniques of the social forestry to farmers and other beneficiaries.

4. Re-developed their abilities to resolve problems in the promotion of social forestry by expanding their knowledge and techniques and by exchanging experiences among participants from other countries.

The target and partners of social forestry even include urban and sub-urban population because of the forest products and impacts.

It can be stated that forest property rights include five aspects and they are land use, transfer, lease, heritage and mortgage. Chinese forest policy reform have been done for many years, but forest property right system reform still can not meet with the need of combating desertification and environmental prevention. Desertification is one of the main environmental problems in China and the main cause is human factors. Deforestation is the most important factor. 
There are many reasons for deforestation but the most important one is farmers are lack of initiative and long plan in managing forest. Because the forests are not their own, and they can not get any benefit from it.

Social forestry is a new concept that aims to establish a sustainable forest resource management. It will probe a new path for the establishment of the technological innovation system in the forestry domain. At the same time, it will impel forestry activity from departmental responsibility to social responsibility, guide and organize the whole of society to participate in the protection, restoration and construction of forest resources and ecological environment according to state forestry development primary goal, impulse forestry industrial development under a new situation, enhance forestry's service quality to the whole society and human being, and bring about extensive scope and greater benefits to forestry development in the 21-th century. It can make a greater contribution towards combating desertification and ecological environment construction in China.

\section{LITERATURE CITED}

CCICCD, (2002): China National Action Program to Combat Desertification. 3-4

CFD, (1998): The Report on Chinese Forest Resource by Chinese Forestry Department, pp20, Beijing (in Chinese)

Chen,D.R., (1998): Chinese Forestry Development and Market Economy. 30pp, Fujihara Syuppansya (in Japanese)

China EnVIRONMENTAL Review 21 $1^{\text {st }}$-1999: http://www,environmentalexpert.com
FEnG, Z.D., (2003): Studies on the Process of Desertification in China, published by Chinese Desertification Research Institue, pp2-6, Lanzhou (in Chinese)

L, Z.Y., (2002): Paper presented at the IUFRO Science. Task Force regional meeting held in India, pp16, July 2002

RrCHARDSON, S.D., (1990): Forests and Forestry in China-Changing Patterns of Resource Development. Island Press, Washington, D.C.

Richardson, S.D.,(2000): Forestry, People and Places: Selected Writing from Five Decades. Business Media Services Ltd., Rotorua, New Zealand

SFA, (1986): The Report on Chinese Forestry Development by the State Forestry Administration in 1986, published by Chinese Forestry Administration, Beijing

SFA, (2000): The State Forestry Administration, Forest Research Statistics of China (1999) (in Chinese)

SFA, (2003): The State Forestry Administration has published its goals for forestry development by 2050 in the Strategic Research on the Sustainable Development of China's Forestry in Chinese Forestry, 12 Issues, 2003 (in Chinese)

TAYLOR, (2000): Dr. Peter Taylor, Education Technical Adviser, Social Forestry Administration in 1986, published by Chinese Forestry Administration, Beijing

WANG, H.C., (2001): Studies on Chinese Forestry, pp 2-3, Chinese Environmental Education Publishing House

ZHANG, (2002): China's Forest Policy for the 21st Century, pp2, Renmin Education (in Chinese)

ZHU, Z.D., (1999): Combating sandy desertification in China, pp33.Chinese Forestry Publishing House (in Chinese)

(Received 8 June 2004)

(Accepted 13 December 2004) 